[15] Lur'e, I. S. (1978). Rukovodstvo po tekhnologicheskomu kontrolyu v konditerskoy promyshlennosti. Moscow: Pishchevaya promyshlennost, 278.

[16] Korkach, A. V., Krusir, G. V., Borovik, I. A. (2014). Possibilities of using synbiotic complex in marshmallow technology of functional purpose. Eastern-European Journal of Enterprise Technologies, 2 (12 (68)), 127-133. doi: 10.15587/1729-4061.2014.23665

[17] Korkach, H., Krusir, G. (2017). Development of innovative technologies of fondant candies with synbiotics. Technology Audit and Production Reserves, 1 (3 (33)), 50-55. doi: 10.15587/2312-8372.2017.93806

\title{
INVESTIGATION OF FOAMING AND HYDRATION PROPERTIES OF COLLAGEN HYDROLYZATE
}

\author{
Nadya Dzyuba \\ Department of restaurant and health food technology \\ Odessa National Academy of Food Technologies \\ 112 Kanatna str., Odessa, Ukraine, 65039 \\ dzyubanadya282@gmail.ru \\ Iryna Bilenka \\ Department of restaurant and health food technology \\ Odessa National Academy of Food Technologies \\ 112 Kanatna str., Odessa, Ukraine, 65039 \\ irinabelenka@gmail.com \\ Anna Palvashova \\ Department of biotechnology, preserved food and beverages \\ Odessa National Academy of food technologies \\ Kanatnaya str., 112, Odesa, Ukraine, 65039 \\ palvashova_ai@ukr.net \\ Elena Zemlyakova \\ Department of restaurant and health food technology \\ Odessa National Academy of Food Technologies \\ 112 Kanatna str., Odessa, Ukraine, 65039 \\ elenazemlyakova00@gmail.com
}

\begin{abstract}
Qualitative parameters of foams, received due to glutin were studied. Technological conditions for receiving food foams were optimized. Their microstructure was determined; it was demonstrated that foam bubbles have the spherical form with the size from $50 \mathrm{mcm}$ to $200 \mathrm{mcm}$ (at the shaking temperature $9^{\circ} \mathrm{C}$ ), at increasing the temperature of foam creation to $20^{\circ} \mathrm{C}$, the mean bubble size reaches $1530 \mathrm{mcm}$.

The data, obtained using IR-spectroscopy demonstrated the presence of free groups, able to bind free water molecules. The obtained microphotos of hydrated glutin demonstrated that the crystal form had not been destructed by the alkaline hydrolysis, partially dissolved at hydratation.

The obtained data give a possibility to recommend collagen hydrolyzate as an effective foaming agent and stabilizer of food systems at producing beverages of raw material fruits.
\end{abstract}

Keywords: rheological properties of food foams, microphoto, collagen hydrolyzate, glutin.

DOI: $10.21303 / 2504-5695.2017 .00424$

(C) Nadya Dzyuba, Iryna Bilenka, Anna Palvashova, Elena Zemlyakova

\section{Introduction}

The last time the worsening of the food status of the population, especially dwellers of megalopolises and unfavorable regions, causes the special interest. The stable deficit of macro- and 
micronutrients, absence of essential and biologically active substances is observed in food rations. It causes the interest to elaborating new fortified compositions of food products using native biologically active substances (BAS). Nutritiology becomes especially urgent in this direction [1, 2]; it helps to select BAS with expressed functional-technological properties and supply the organism with full value proteins, vitamins, macro- and microelements [3-5].

The special interest is caused by the secondary milk raw material that includes physiologically important substances in its composition. The one of directions of using the secondary milk raw material is the elaboration of beverages of the aerated (foam) structure [6-8].

But the secondary milk raw material doesn't contain enough protein, able to foaming in its composition that limits its use at foam products manufacturing. For solving this problem, it is most promising to use high-molecular foam agents of the protein nature, namely collagen hydrolyzate (glutin).

Today collagen of fish scale finds its usage in the cosmetic, medical, pharmaceutical industry and in treating-prophylactic food products manufacturing. Fish collagen is close to one of the human connective tissue and skin, collagen preparations of scale of fresh-water fishes, living in clean water bodies, don't cause allergic reactions. The collagen ability to stimulate the generation of own collagen of the organism and also its water-holding properties favor different cosmetic preparations and healthy food products creation [9].

Thus, glutin use as a foaming agent allows to widen the assortment of functional products and beverages with expressed bioprotective properties.

The aim of the work is to study rheological properties of food systems, containing glutin that allows to widen the assortment of products with bioprotective properties.

The following tasks were set for attaining this aim:

- to study the influence of technological parameters on glutin foaming and foams structure;

- to study the influence of technological parameters on glutin hydration.

\section{Materials and Methods}

The studies were carried out on the base of the modern scientific laboratories:

- the department restaurant and health food technology of the Odessa National Academy of Food Technologies (Ukraine); Ukraine).

- the laboratory of the Physical-chemical institute, named after A.V. Bogatsky, (Odessa city,

The objects of the study were:

- glutin, received by the alkaline hydrolysis of the collagen-containing fish raw material;

- milk serum (USST 4552:2006);

- agar (SST 16280-2002 Ukraine);

- apple pectin (USST 6088: 2009 Ukraine).

The following equipment was used for the research:

- To receive foams - a blender (PHILIPS HR-1633/80, China);

- Refrigerated cabinet (RC-0,4 MC, Republic of Mari El, Russia);

- Electric weights (Rotex RSK 10-P, China); Ukraine);

- For keeping samples temperature - a water bath for two working sections (WB-4 (R),

- To realize the microscopy of samples - microscope (Biolam P15 (Lomo, Russia) with the digital camera-ocular ScopeTek DCM-130 E 1.3 Mp (Hangzhou Scopetek Opto-Electric Co., China); - Absorption IR-spectrums registration was realized on the infrared spectrophotometer FTIR-8400S, made by Shimadzu (Japan);

- Collagen hydrolyzate refinement was realized on Fon Adrenn vibrator (Germany).

\section{Experimental procedures}

For realizing the experiments, $\mathrm{CH}$ was refined on For Adrenn to homogenous particles. The protein foaming ability was calculated by the formula: 


$$
A=\frac{H_{f}}{H_{p . s .}} \cdot 100 \% \text {, }
$$

where $A$ - the protein foaming capacity, $\% ; H f$ - the foam height above the liquid level, $\mathrm{cm}^{3} ; H_{p . s .}-$ the protein solution height before foaming, $\mathrm{cm}^{3}$.

In the aspect of construction liquid foams of gas babbles, separated by liquid layers (lamelae) are most interesting. The geometric form of gas bubbles in liquid foam depends on the ratio of gas and liquid volumes in it, polydispersity degree and method of bubbles packing.

Food foams were received at the following technological parameters $\mathrm{pH}=6, t=9{ }^{\circ} \mathrm{C}$, shaking time 3 minutes, collagen hydrolyzate concentration $6 \%$.

For determining the structure and dyspersity of the foam, received using collagen hydrolyzate, the microfilming of the sample, preliminarily frozen to the temperature $(-10 \ldots-12){ }^{\circ} \mathrm{C}$ was realized. The microphoto of the foam is presented on Fig. 1. The photomicrography of the foam was realized by the method of the direct determination of bubble sizes using AMCap with the further photography in Bandicam program. The photography was carried out in transmitted light at 900 times magnification.

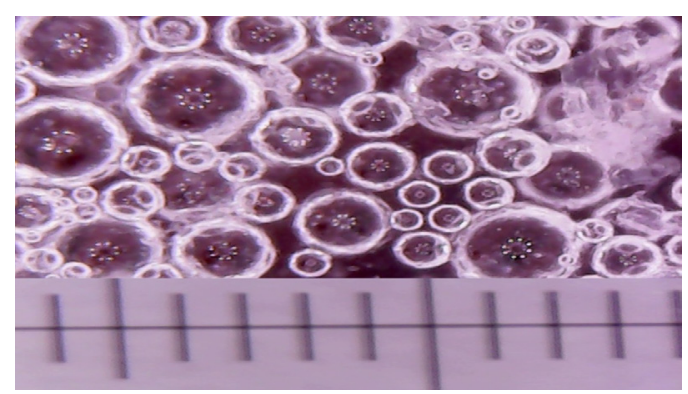

Fig. 1. The microphoto of the foam, received using collagen hydrolyzate (1 DIV=0,1 mm)

It was established, that air bubbles in the foam of collage hydrolyzate have the spherical form with the size from $50 \mathrm{mcm}$ to $200 \mathrm{mcm}$. Interpore partitions are observed in the sample that explains the high stability of the received foam structure. At increasing the shaking temperature to $20{ }^{\circ} \mathrm{C}$, foam bubbles sizes increase (the mean size of a bubble reaches $1530 \mathrm{mcm}$ ).

The foam stability was assessed by the foam height after its keeping during 20 minutes in quiet and calculated by the formula:

$$
S=\frac{H_{f}}{H_{f . k .}} \cdot 100 \%,
$$

where $S$ - the foam stability, $\% ; H_{f}$ - the foam initial height, $\mathrm{mm} ; H_{f . k}$ - the foam height after keepe ing during $15 \mathrm{~min}, \mathrm{~mm}$.

The absorption IR-spectrums registration was realized on the infrared spectrophotometer FTIR-8400S, made by (Shimadzu (Japan) in the diapason $4000 \ldots 400 \mathrm{~cm}^{-1}$. The decryption of IR-spectrum was realized using [10].

Tablets, prepared by pressing with $\mathrm{KBr}$ excess were used for the analysis. The filler mass was $150 \mathrm{mg}$, studied sample $-1,5 \mathrm{mg}$. The received mixture was refined on Fon Ardenn vibrator during $4 \mathrm{~min}$. The received powder mass $(100 \mathrm{mg})$ was used for preparing a tablet. Then the vacuumization of the preparation was carried out in the press-form under pressure $150 \mathrm{~kg} / \mathrm{cm}^{2}$.

The analysis of the received IR-spectrum of collagen hydrolyzate (glutin) demonstrated the presence of valence vibrations and $-\mathrm{C}=\mathrm{I}$ groups of non-ionized and ionized acids (Fig. 2) [10]. The intense broad band with the absorption maximum at $3400 \mathrm{~cm}^{-1}$ demonstrates the presence of hydroxyls in the system of hydrogenous links. The data, obtained using IR-spectroscopy demonstrated the presence of free groups, able to hydratation.

The degree of collagen hydrolyzate swelling was assessed as an increment of the product relative to the initial object and was calculated by the formula, \%: 


$$
n=\frac{H}{H_{\mathrm{v}}} \cdot 100 \%,
$$

where $H$ - the increment of the product volume, $\mathrm{cm}^{3} ; H v$ - the initial volume of the product, $\mathrm{cm}^{3}$.

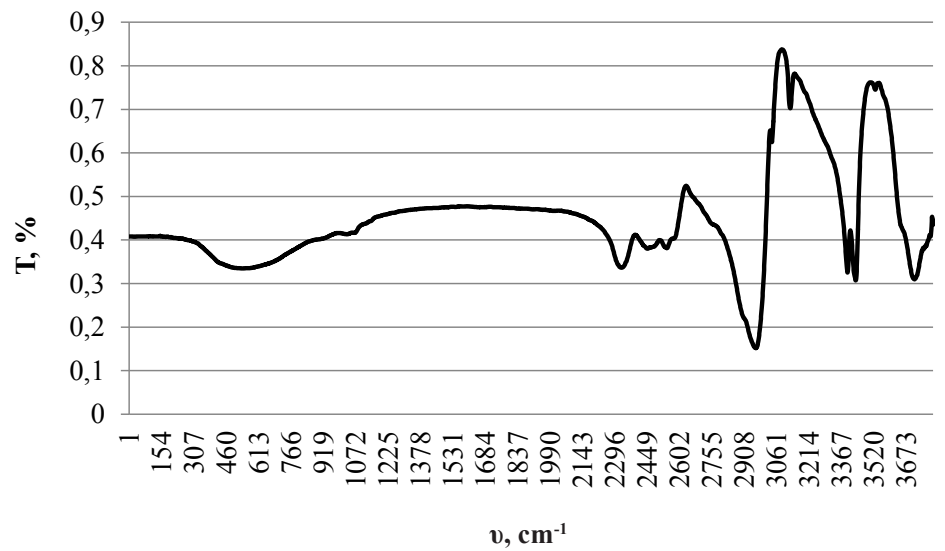

Fig. 2. IR-spectrums of collagen hydrolyzate

The batch $25 \mathrm{~g}$ was taken in the cylinder $500 \mathrm{~cm}^{3}$, filled with the liquid fraction - water with the different $\mathrm{pH}$ value $(\mathrm{pH}=2,3 ; 7,0 ; 10,1)$. $\mathrm{pH}$ values were chosen, based on mean $\mathrm{pH}$ values at gastrointestinal digestion.

The liquid phase volume was 5 times more than the solid phase volume (collagen hydrolyzate). The measurements of changes of the solid phase volume were realized each hour during 7 hours.

The kinetics of the swelling process is described by the equation:

$$
\frac{d \varphi}{d \tau}=C \cdot\left(\varphi_{\max }-\varphi_{\tau}\right)
$$

where $\varphi_{\max }-$ the limit swelling degree; $\varphi_{\tau}-$ the swelling degree to the certain moment of time, $\tau$; $\mathrm{C}$ - the swelling constant that depends on the product nature and processing temperature.

As a result of the integration, the equation (2) looks as:

$$
C=\frac{1}{\tau} \cdot \ln \frac{\varphi_{\max }}{\varphi_{\max }-\varphi_{\tau}} .
$$

After determining the swelling degree in certain time intervals (each hour) we can get curves, named kinematic swelling curves. These curves have an experimental character and straighten at correspondent semi-logarithmic coordinates (linear scale - swelling time, logarithmic $\left.-\lg \left(\varphi_{\max }-\varphi_{\tau}\right)\right)$. So, analogously to the heat exchange process at the regular thermal regime, the equation of straightened curves looks as following at the swelling, relative to the mass exchange process:

$$
\lg \frac{\varphi_{\max }}{\varphi_{\max }-\varphi_{\tau}}=\frac{\tau}{f_{n}}
$$

where $\tau$ - the time of attaining the given swelling degree $\varphi_{\tau} ; f_{n}-$ the constant of the swelling inertia - time, necessary for 10 times decrease of the difference between the maximal swelling value $\varphi_{\max }$ and given one $\varphi_{\tau}$ or time, necessary for the swelling degree to reach the height that is $90 \%$ of the maximal one, minutes.

$f_{n}$ value is determined as the time of one logarithmic cycle, passed by the curve; it allows to compare swelling speeds of different material types, and also the swelling speed at different temperatures. 
Microphotos (magnification $\times 900)$ of dry and swelled collagen hydrolyzate $(\mathrm{pH}=6$, swelling time 1.5 hours) are presented on Fig. 3.

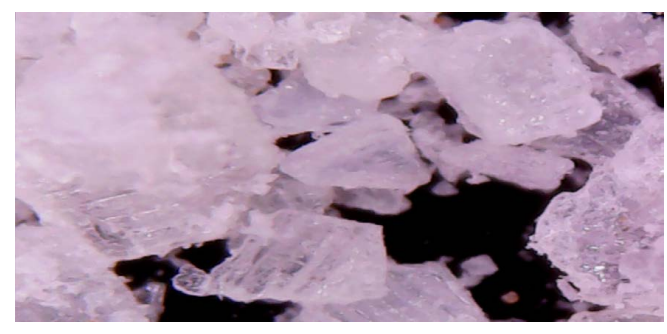

$a$

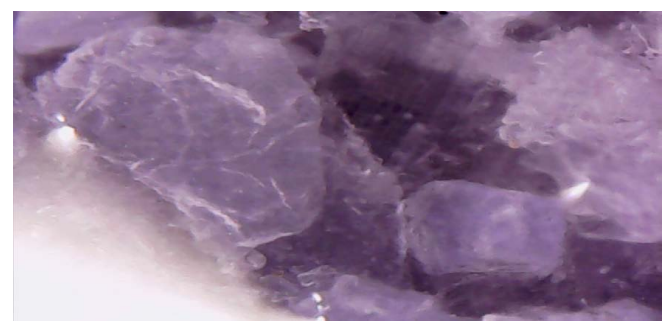

$b$

Fig. 3. The microphoto of dry and swelled CG ( $a$ - dry glutin, $b$ - swelled glutin)

The obtained microphotos give a possibility to see that the structure of glutin nanoparticles changes. The crystal form, not destructed by the alkaline hydrolysis partially dissolves. Glutin particles gain more soft and loose structure.

It conditions the creation of pores in particles, which can play the important role in heavy metals and toxic substances sorbing and removal from the human organism.

\section{Conclusions}

1. It was established, that the foam of spherical bubbles forms at receiving foams with glutin at rational technological parameters $\left(\mathrm{pH}=6, t=9^{\circ} \mathrm{C}\right.$, shaking time 3 minutes). The bubbles size varies from 50 to $200 \mathrm{mcm}$ that favors the deceleration of the liquid phase outflow from the intermemranous space and structure stabilization.

2. The data, obtained at hydratation demonstrated the glutin ability to bind water molecules effectively, at that the crystal form of glutin turns to the soluble one. Such glutin ability gives a possibility to position it as a stabilizer of the food system. The presence of free groups in a protein molecule of collagen hydrolyzate gives a possibility to develop the scientific direction in the study of its sorption properties that may give a push to the development of the new direction in biologically active additives.

\section{References}

[1] Blake, L. H., Jenner, C. F., Barber, A. R., Gibson, R. A., O’Neill, B. K., Nguyen, Q. D. (2014). Effect of waxy flour blends on dough rheology and bread quality. International Journal of Food Science \& Technology, 50 (4), 926-933. doi: 10.1111/ijfs.12710

[2] Iorgachova, K., Makarova, O., Khvostenko, K. (2016). Technological characteristics of yeast-containing cakes production using waxy wheat flour. Food Science and Technology, 10 (4), 37-41. doi: $10.15673 /$ fst.v10i4.252

[3] Ratsionalne kharchuvannia liudei litnoho i starechoho viku (2006). Kyiv: T-vo «Znannia» Ukrainy, 36.

[4] Telezhenko, L. M., Kushnir, N. A., Todorova, M. M. (2013). Modeliuvannia ratsionalnoho kharchuvannia. Obladnannia ta tekhnolohii kharchovykh vyrobnytstv, 30, 306-311.

[5] Dzyuba, N. A., Zemlyakova, O. V., Pedak, K. H. (2016). Osnovy modeliuvannia ratsionalnoho kharchuvannia v umovakh porushenoho ekolohichnoho stanu. Prohresyvni tekhnika ta tekhnolohii kharchovykh vyrobnytstv restorannoho hospodarstva i torhivli, 1 (23), 142-153.

[6] Sarafanova, L. A. (2004). Pishchevye dobavki: entsiklopediya. Saint Petersburg: GIORD, 808.

[7] Kholmberg, K., Yenson, B., Kronberg, B., Lindman, B. (2007). Poverkhnostno-aktivnye veshchestva i polimery v vodnykh rastvorakh. Moscow: BINOM. Laboratoriya znaniy, 528.

[8] MakKenn, B. M. (2008). Struktura i tekstura pishchevykh produktov. Produkty emul'sionnoy prirody. Saint Petersburg: Professiya, 480.

[9] Gomez-Guillen, M. C., Gimenez, B., Lopez-Caballero, M. E., Montero, M. P. (2011). Functional and bioactive properties of collagen and gelatin from alternative sources: A review. Food Hydrocolloids, 25 (8), 1813-1827. doi: 10.1016/j.foodhyd.2011.02.007

[10] Tarasevich, B. N. (2012). IK spektry osnovnykh klassov organicheskikh soedineniy. Moscow, 55. 